
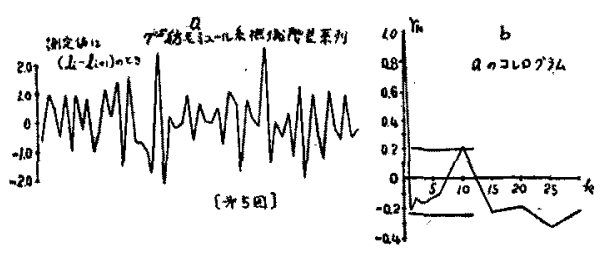

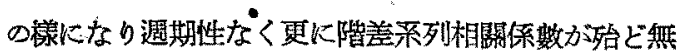

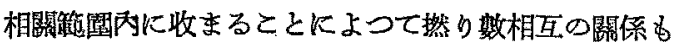
なくなつて，踏差值が互に猲立になる。これは極く僅 かな系しか得られない埸合，試料個數を大きく且つ試 料を敀して採るととが出來ない洔に有效て階差をとる ととによつて他の階差犆と然りむらを比較するととか゚ 出來る。

\section{4. 結論}

系の撚りむらは重量むらを考慮するととなく結諭す るととは性來ないが，撚りむらの根本的な㫮性質につ いては以上のととが云える，とれを綜合するると，

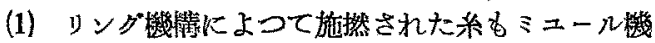

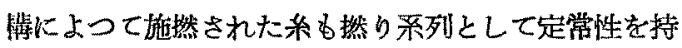
つている。との定常性をすつているととは工業的には

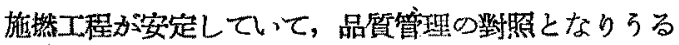
ととを示し，理諭的には系を磪率過程として捉える基 礎となるととを示している。

(2) リング機棈による系は撚りむらが明白な遇期性

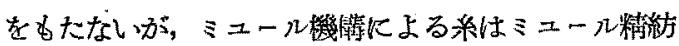
機の1ストレッチを單位とした週期がある。

(3) リング浇構による系は施璒が精紡機のフロント ローラーを出た淔後にかけられた撚りて大凡の撚りも

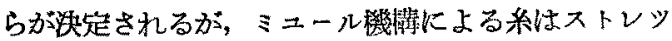
于後最後の施撚により撚りが傳播するよろで方る。そ の結果リング糸は部分的に然りむらが統計的に獨立で

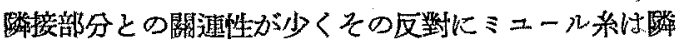

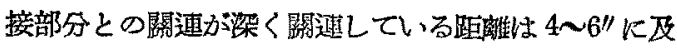
ぶ。そ水故試料を他の然りむらと比校する感保獨立 な值としてとる殔に 4〜6" 以上離さなければならない。 自己相關を不均齊度の目喀とした洗，ミニール系の姐 く系の部分的㬎りむらが相互關速をるつている方が， 均狧庭が息好ですると云える。

（4）ミニール絬毛糸の㬎りもらの如く週期をもつて

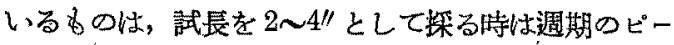

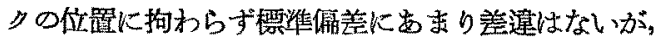
試長を或る程度大きくすると試料を㛊名場所火よつて

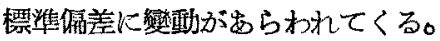

（5）糸の隣接した部分の階差を测定随としてとる特 は，週期的なむらは消失し測定檤も互に摆立になつて

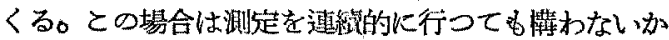

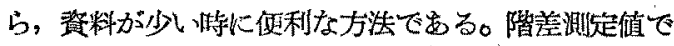
他の糸と比校する洔性勿諭他の系子階差测定倠をとら ねばならない。品啠管理に怙いて撚りむら学象とす る歭は階差法が計算容易な點から有効であるる。

向本研究は文部省科然研究辈によるものでミーール 紡毛系の研究については，昭和24年11月䋳維學會秋期

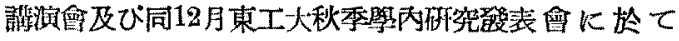
「调期的な斑のある絲のサムブリングKついて」第

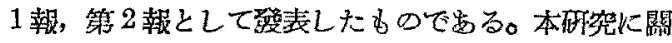
する資料は鐘紡南千住工場の竹网平一郎君の御厚意に 與つた。文苴驗その他について怔東工大の延原茂光君 に拹力していたがいた。と〉に厚く感謝の意を表す。

文 献

（1）成田裕，三本和雄，織學誌 系・スライパの品 筫火關する破究（第1 報）

(2) Kendoll. The Advanced Theory of Statistics vol II. p. 408,1948

(3)，(4) 統計比值表 河出畫屏

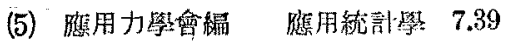

\title{
反毛ナイロンによる混紡の矼劣 (2)
}

高分子化繁湤畣

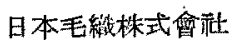

\section{荒开深吉小島茂三} 青 木 常 藏

\section{1. まえがき}

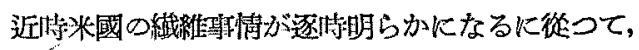
鼬紡・混䋨の间題か河く比人の注目する所となつた。 
との闍題について茾井は以前からその重罗性を演感 し機會ある每にとれを腊調したのであるが，我國に於

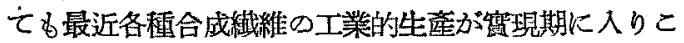
の開邀の重琶性がいよいよ切宽に感ぜられるようにな

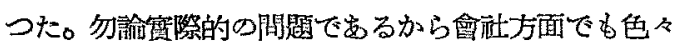
矿究されているとととは舁うが結果の会表されている

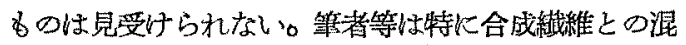
紡に興味を持ち,ナイロンスフの混紡を企雷したが經 望その他の筫で售現し得なかつた。幸にして過般ナイ ロン製品の屑物を人手出來たのてとれを反毛し，てれ と羊毛との混䄱を梳毛紡䋶法によつて試みた所，橪ね 所期の結果を得たのでととに報告せんとするものです る。

\section{2. 惯驗材 料}

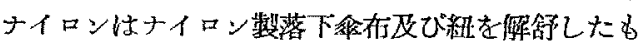
ので，筆者等の反毛法によれば3in 以上の繊䊒が得ら れる。

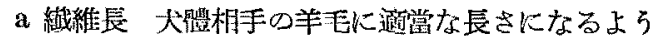
K設計製作した。多少のミスカット女倈たが，出來 たもののステープルダイヤグラムは，筧る相手の羊毛

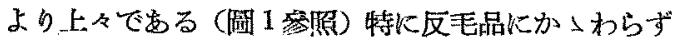

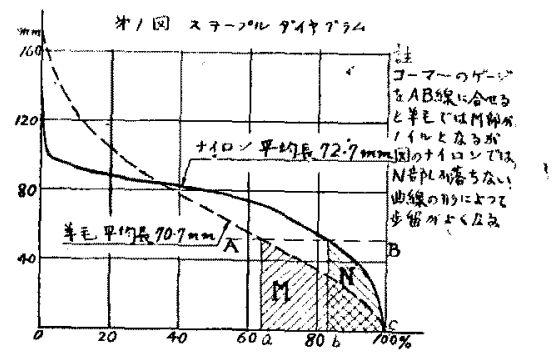

ステープル，ダイヤグラムにふくらみがあるととがよ

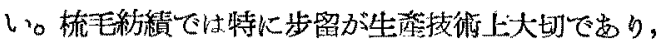
コーマーのダージをどてで拥えて Noil に落すかが原

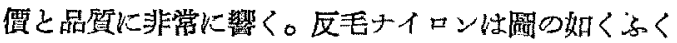
らみがむるので, 羊毛よりも落物がはるかに少ない、と のととは出來た Noil を秤量する迄もなく， S.D.を 入念作つて，とれから算出すれば，その步留住計量 仙來る。とのととはナイロン反毛スフと，羊毛とを同 值で置えたとすると、ナイロン反毛ス・フよりはより 多く精系を作ることが什來るから分がいということ になる。反非ス・フでなく，新品テイロッ，大・フの 㙏合には更によくなるとと勿論であるーとのどとは單 にカイロンK限らず，ビニロンですテミランですス

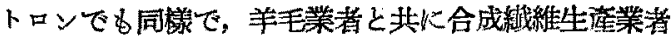
が特に注目すべき利默である。

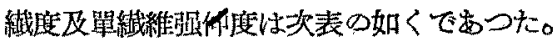
b. 㵶度は

\begin{tabular}{|c|c|c|c|c|}
\hline & 平 均 & 最 大 & 最 小 & 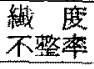 \\
\hline ナイロン,ス・フ & $19.1 \mu$ & $21.7^{\circ}$ & 15.5 & $7 \%$ \\
\hline 差 (裂考) & 21.5 & 40.3 & 10.8 & $21 \%$ \\
\hline $\begin{array}{l}5 \pi z-\pi, \\
x-y\end{array}$ & 19.0 & 24.8 & 12.4 & $11 \%$ \\
\hline
\end{tabular}

c. 單䤮維强仰度

\begin{tabular}{|c|c|c|c|c|c|c|c|c|c|}
\hline \multicolumn{6}{|c|}{ 强力 } & \multicolumn{4}{|c|}{ 伸臤 } \\
\hline & $\pi$ & & 曼小 & $\begin{array}{l}\text { 强力 } \\
\text { 不整 } \\
\text { 率 }\end{array}$ & $g r / a$ & 平均 & & 最' & 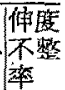 \\
\hline $\begin{array}{l}\text { ナイン } \\
\text { ス }\end{array}$ & 18.0 & 22.6 & 14.8 & $\begin{array}{r}\% \\
11.8\end{array}$ & 4.9 & $\begin{array}{r}\% \\
224 \\
\end{array}$ & 27.5 & 18.8 & $\begin{array}{r}\% \\
8.4\end{array}$ \\
\hline 羊 电 & 8.5 & 12.3 & 5.4 & 21.0 & 1.7 & 31.8 & 45.0 & 13.8 & 13,2 \\
\hline $\begin{array}{l}\text { ビスコー } \\
\text { スス・フ }\end{array}$ & 7.3 & 10.3 & 6.1 & 13.8 & & 17.6 & 22.5 & 15.0 & 9.5 \\
\hline
\end{tabular}

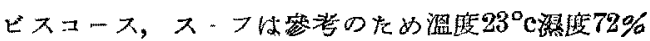

上表で注目すべき點山繊度, 强帅度共不整率の少な いととである。アメリカの化樴界が如何に均齊な製品 を作るととに注意しているかを知ると共に，これをつ かえば紡績工程を非常に省略し得るととを知る，羊毛 梳毛紀績工婜は棉紡等に比して高い，その原因が、洗毛 工程のあるととと共に，カード以後のバックウオシン

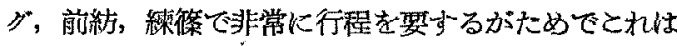
瀻維が太くて，長く港縮のあるためでのみなく，羊毛 自體に不整率の蒠いととが現在の梳毛紡績機娥を必装 とした琀も䟞くない，不整率が少ないととはダプリン グの回教を少なくし工程を省略し，從つてい〉系をや ナくつくる可能性がある一このことはよく山來た化瀻 一般に云える。

\section{3. 紡 績操作}

混紡に祭し先ず原毛調合でするか、、スライバー調合

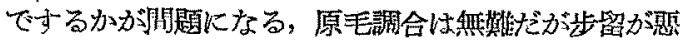
くなる。ナイロン10\%20\%30\%共スライバー調合を行 つた。カードでは大して間题はなく, フライ等るビ コース, スフ程膄, インタ一の作業は签易, コーマ 一はや小困蜼でコーマーに於けるラッピングはブライ ト，ス・フと同稂必ずしも圓猾比行かず，前紡工程 は概ねどスコース，ス・フと大差はないがイロン， 
ス・フの混紡率が10\%から20\%30\%と進むにつれでフ ロントローラーに控付く傾问が强くなり作業や〉困鹳 を加5，フロントローラーの材質に，更に研究を加え， 時にはプラステック，合成ゴム等がよかるろとの暗示 るろけた。精紡は10\%20\%程度てはさして闍題はない が30\%になると，前紡同栐フロント，ローラーへの俩 付荖しく糸切數がすす，一ニップ當りの系切數を謂べ たとてろ，10\%で 0.58本であつたものが20\%ナイロン 混紡て 0.87 本，30\%で 1.65 本となつた，湿紡率が高く なるにつれて考慮を要する點でする。(其他省略)

\section{4. 精米の批判}

\begin{tabular}{|c|c|c|c|c|c|c|c|c|}
\hline & 混紡率 & 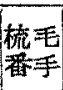 & 撚 & 强力 & 伸度 & 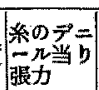 & \begin{tabular}{|l|} 
利用 \\
率
\end{tabular} & 浿浱 \\
\hline 㻎 & & 32.6 & 38.3 & $\begin{array}{r}\mathrm{gr} \\
134\end{array}$ & $\begin{array}{r}\% \\
10.3\end{array}$ & $\begin{array}{r}\% \\
0.548\end{array}$ & $\begin{array}{r}\% \\
31.6\end{array}$ & \begin{tabular}{|l|l}
6 & $19^{\circ} \mathrm{c}$
\end{tabular} \\
\hline 系 & ino & 32.5 & 36.1 & 161 & 10.6 & 0.677 & 33.5 & \\
\hline 㘽 & $20 \%$ & 31.7 & 35.0 & 199 & 13.0 & 0.791 & 34.4 & $175 \%$ \\
\hline & 同 $30 \%$ & 32.4 & 39.1 & 275 & 13.7 & 1.118 & 43.0 & \\
\hline 䁵 & チА 망 & 27.5 & 38.0 & 798 & 16.8 & 2.752 & 59.6 & $628^{\circ} \mathrm{c}$ \\
\hline
\end{tabular}

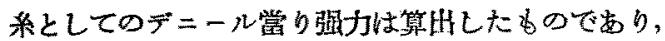
利用茶は次式による。

$$
\text { 利用率 }=\frac{\text { 米のデ }=-n \text { 黨り强力 }}{\mathrm{a} \times\left(1-\frac{a}{100}\right)+\mathrm{b} \times \frac{a}{100}} \ldots . . . . . . . . .(1)
$$

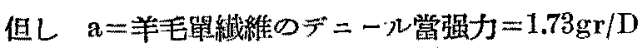
$\mathrm{b}=$ ナイロソ單䋘維のデニー゙ 當强力 $=4.62 \mathrm{gr} / \mathrm{D}$

$a=$ チイロン混入茶 $\%$

\begin{tabular}{|c|c|c|c|c|c|c|c|c|}
\hline & 湿紡率 & 番手 & 撚 & 强力 & 伸㝗 & $\begin{array}{l}\text { 糸の } \\
\operatorname{gr} / \mathrm{D}\end{array}$ & $\mid$ & $\begin{array}{l}\text { 淄嗐 } \\
\text { 鹿 }\end{array}$ \\
\hline 双 & 維 毛 & $32.7 / 2$ & 上 17.5 & $\begin{array}{c}\mathrm{gr} \\
252\end{array}$ & 9.0 & 0.516 & & 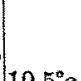 \\
\hline & ナイ 뭉 & 33. $/ 2$ & $\begin{array}{l}\text { 卞 } 17.1 \\
55.6\end{array}$ & 305.5 & 9.8 & 0.632 & 31.3 & \\
\hline 陚 & $" 20 \%$ & 32. /2 & 卡 17.5 & 401.5 & 12.2 & 0.806 & 35.0 & $84 \%$ \\
\hline 驗 & $" 30 \%$ & $31.7 / 2$ & 卡 16.9 & 460.5 & 12.2 & 0.915 & 35.2 & \\
\hline
\end{tabular}

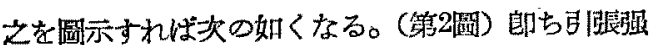
カは反毛ナイロンを一割入れるととにより二割上早し，

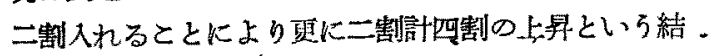
果になつた。伸度についても表の如く，良好な絬果を 示している。之を系のデニール賞り强力以損算すると, 表の如く疑著な问上が認められる。又利用率を(1)式に

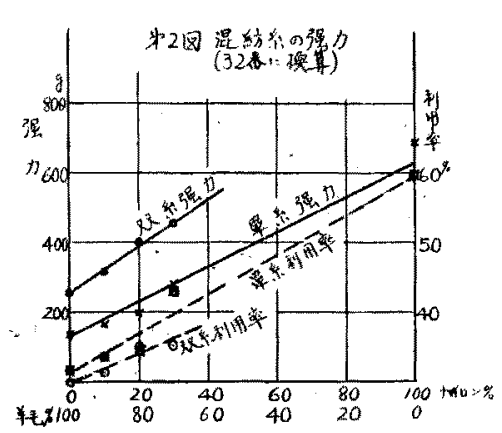

よつて算出 すると，混 紡率の上が るにつれて, 利用率が著 しく上つて いるととが わかる。郎 ち利用䗆の 向上によっ て繊維の $\mathrm{gr} / \mathrm{D}$ はナイロンは上迅羊毛の三倍弱でする が絍したときには五偣といら結果を示した。紡績方 法如何により必らずしもか力る結果になるといえない

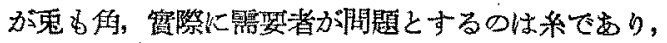
蟣物であるのでかっる結果があらわれたととは注目に 值する。單に引㖘强力だけでなく，而久力になると，

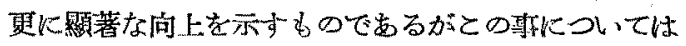
別の機會に迌べるととにする。

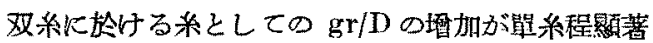
でないととに關しては，畹驗がメリヤス用原系で出る とと，上下撚の關俰其他が洘えられるが，普通䅨系等 に現われる現像とは逝の佰尚にあり，今後䨤に詳細な 檢討を姴する呫と思料される。

\section{5. あとがき}

以上を要䄪すると

a. 普通の綿織物，羊毛蟣物を反毛再生したもので は紡毛紡績，落綿紡績による外優良な市場栍出る紋を 紡出するととが困難であるが，骤良な合成絒維にあっ ては, 梳毛紡漬に使用し得る繊維が炣生し得るととを

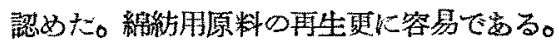

b. ナイロンス・フの泿紡により羊毛混紡系の引張

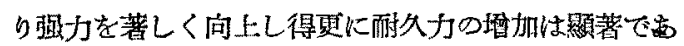

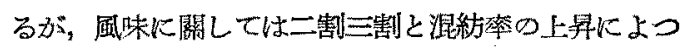

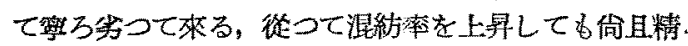
系の昧を招とさないためには，混入すべきナイロン其 他の合成繊維のデニールKつき，更に詳細な研究が必 要びすり,ナイロンKついていば, 窝る太いデニー

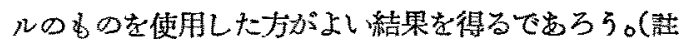

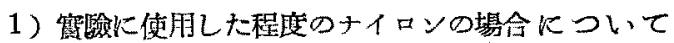

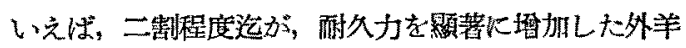

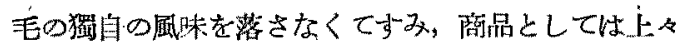

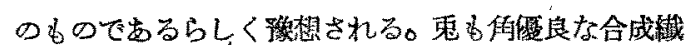


維の混紡により羊毛は却つてその品位を高凶得るであ ろろ(このととは單にナイロンK限らず，類似なポり

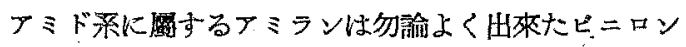

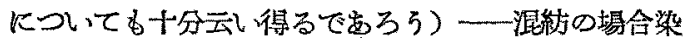
色性の不同がよく間題になるが，各繊維の染着性は異

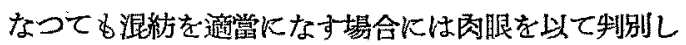
得ず，泿紡率の少ない場合には左程間題とするに賞ら

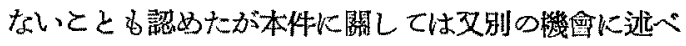
る。

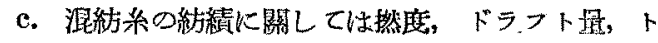
ップローラーの材質, 其他機械の政造, 溫濕庭の注整;

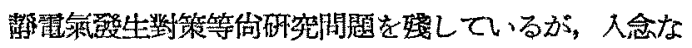

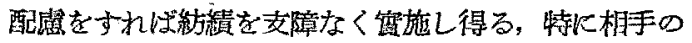
羊毛の洗毛工程の向上Kより米國の如く Back Washing を省略し得るととになれば, 却つて全般的に工 程を著しく短維し得て，䋓縝工鼠は著しく魀減し得る 見とみがある。

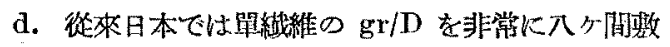
とり立ていいるが，原料か違、，そのステープルがイ ヤグラムがことなり，紡積方法がととなつたときは必

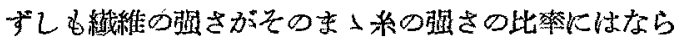

ない(註 2) 本馏驗以於ては羊毛の 2.9 倍のナイロン 反毛を使用し，系としては 5 倍のるのさえ得ている。 單に單縤維の $\mathrm{gr} / \mathrm{D}$ K止まらず系として，更に綪物と

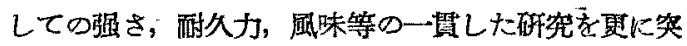
达んでやるべきである。

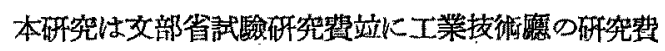
の一部によつたるのですり，女部省及び通產省掌同の

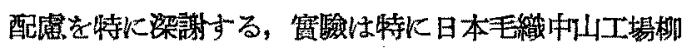

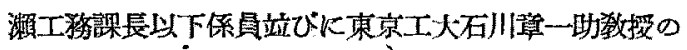

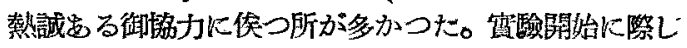

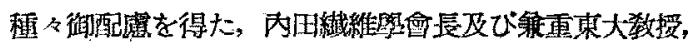
簒田京大敉授に對しても深く感謝する。（本稿は昭和

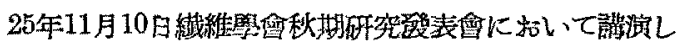
たものである)

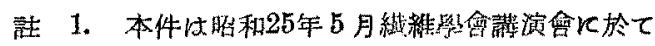
讙逃した。

2. 阙一㨫の瀻維を゙同一紡續法に上つて紡出す

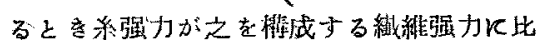
例することは昭和13年大阪に於ける瀻維綜

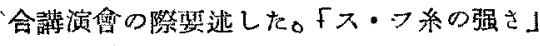
照。

\section{高周波誘電率による繊維水分率测定法について（第 1 㫰）}

\begin{tabular}{|c|c|}
\hline 富士紡緽株式會社 & 坂上恒次郎－江端 \\
\hline 日東紡纈株式會社 & 甲斐野市三郎－田中 \\
\hline 株式會靵聚洋工㸁融 & 高岸㮡次郎 \\
\hline
\end{tabular}

\section{1. 緒 言}

綿繊維（原棉，フップ，スライバ一等）の如き纎維

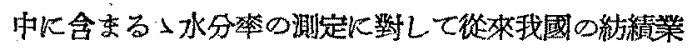
界に於て行われている方法は一般に $2 \mathrm{KW}$ 程度の雷熱

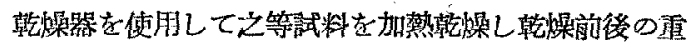
题を天科を用いて計測し下式により算出するるのです る。

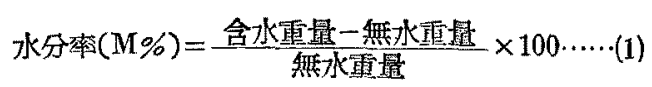

然したらこの方法は周知の道り下記の如き缺默を有
してる。

(1) 1 回の測定に長時間 (少くとも1時閒以上) を 妿する。

(2) 電力消翼量が大さい。

(3) 試料の消耗最が大さい。

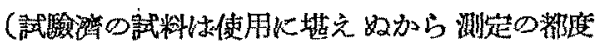
生產原料を無䭾にててい)

(4) 人件軉が垛くない。

とれらの售缺孯を克服せ九とする政良研究が內外各 方面で行わ的電氣を利用する珯方式が性に登場したが

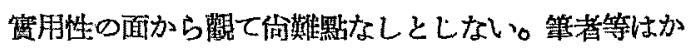

